Doi: HTTPS://DOI.ORG/10.23910/IJEP/2018.5.4.0270

\title{
Suitability of Kitchen Waste Water in Agriculture
}

\author{
Mini Abraham*, Kurien E. K., Bhindhu P. S and Gilsha Bai E. B.
}

Agronomic Research Station, Kerala Agricultural University, Chalakudy, Kerala (680 307), India

\author{
Corresponding Author \\ Mini Abraham \\ e-mail: minielsu@gmail.com
}

\author{
Article History \\ Article ID: IJEP0270 \\ Received in $25^{\text {th }}$ August, 2018 \\ Received in revised form $10^{\text {th }}$ October, 2018 \\ Accepted in final form $22^{\text {nd }}$ October, 2018
}

\begin{abstract}
Water has become a scarce input in agriculture. Reuse of household waste water is helpful in solving water scarcity problems in household agriculture during summer months. Reuse of waste water for garden irrigation should be encouraged in urban and rural households. A study was conducted during the year 2016-2017 at Agronomic Research Station, Chalakudy to assess the water quality of household waste water for reuse in agriculture. Samples were collected from households of different localities and laboratory analysis was conducted to assess different quality parameters. Physio-chemical parameters such as $\mathrm{pH}, \mathrm{EC}$, chloride, carbonates, bicarbonates, sodium, potassium, boron, calcium, magnesium, SAR and RSC were analyzed. It was found that all the parameters tested were within the safe limits and water is moderately suitable or suitable for irrigation. Presence of heavy metal such as lead, chromium and nickel was analyzed and found within the permissible limits in kitchen waste water. Observation on quality parameters of kitchen waste water showed that EC, SAR and boron were low, but RSC ranged from low to medium level. In continuation, a further field trial on okra (var. Arka anamika) was conducted using kitchen waste water during the summer season in the year 2016-17. Performance of the crop was compared with the crop irrigated using normal well water. Yield of the crop irrigated using kitchen waste water was $6.20 \mathrm{~kg} \mathrm{plot}^{-1}$ while it was only $4.10 \mathrm{~kg}^{\text {plot }}{ }^{-1}$ with normal well water. Household kitchen waste water is a very good source of water for irrigating homesteads.
\end{abstract}

Keywords: Kitchen waste water, physico- chemical properties, okra

\section{Introduction}

Water is the most important and scarce resource in Agriculture. In urban, peri-urban and even in rural areas, water scarcity is one of the major problems which affect the cultivation of vegetables. Recycling domestic wastewater is becoming an important part of water management (Angelakis et al., 2012). Among the various existing types of waste water management, recycling of domestic waste water is easier and can be implemented in every household (Nwakonobi, 2015). Kitchen waste water generally contains food wastes which includes carbohydrates, proteins, fats and also soaps and detergents from utensil washings (Lavik et al., 2009). Household wastewater is a source of water for irrigating homesteads if suitable treatment systems are available (Murali and Lakshmipriya, 2014; Chaillou et al., 2011). Grey water (GW) which includes wastewater from urban areas consisting of water from showers, washing machines, kitchens sinks etc. generated from population of a million people may be enough to irrigate up to an area of 15000-35000 hectare (Abdel-Halim et al., 2008). This can also lead to a considerable reduced water demand (Karpiscak et al., 1990; Okun, 1997).

Swetha et al. (2013) also reported that kitchen waste water can also be used for agriculture or gardening purpose and if oxidized can also be used for rearing fish. Reuse of household waste water is necessary for solving water scarcity problems during summer months. The beneficial reuse of wastewater also helps to decrease its impact on the environment.

The end use of wastewater determines the required quality of the water and management procedures required to ensure safety. WHO and several countries have developed guidelines and standards for the safe use of wastewater in agriculture and other settings (WHO 2006a).

Phosphorus, sulphates, heavy metals like iron are the impurities generally found in household waste water which includes kitchen and laundry waste water. A study was carried out as a part of the Irrigation water management project of AICRP at Agronomic Research Station, Chalakudy, Kerala Agricultural University to assess the water quality of kitchen water for reusing in agriculture during the year 2016-17.

\section{Materials and methods}

A study was carried out as a part of the Irrigation water management project of AICRP (All India co-ordinated Research Project) at Agronomic Research Station, Chalakudy, Kerala 
Agricultural University to assess the water quality of house hold waste water for reusing in agriculture.

\subsection{Quality analysis}

Survey was conducted in and around $20 \mathrm{~km}$ from the station for the collection of kitchen waste water from different types of households in urban, peri-urban and rural areas. As a preliminary study, 30 samples of each were collected and analysed the physico-chemical parameters like $\mathrm{pH}, \mathrm{EC}$, chloride, carbonates and bicarbonates (Singh et al., 2010). The laboratory analysis for other parameters such as sodium, potassium, boron, calcium, magnesium, SAR, RSC and presence of heavy metals were also done (Tandon, 1993). Nutrient content and biochemical oxygen demand of kitchen waste water and normal water were also analysed.

\subsection{Field tests in vegetable crops}

A field trial in vegetable crop, okra (var. Arka anamika) was conducted using kitchen waste water during the summer season in the year 2016-17 and performance of the crop was compared with that of normal fresh water irrigated crop. Observations on growth and yield of the crop were noted.

\subsection{Field tests in fish farming}

A field trial in fish farming using fish fingerlings of Tilapia was conducted to check the suitability of kitchen waste water.

\section{Results and Discussion}

\subsection{Quality analysis}

Samples collected from households of different localities were analyzed to assess different quality parameters. Physicochemical parameters such as pH, EC, chloride, carbonates, bicarbonates, sodium, potassium, boron, calcium, magnesium, SAR and RSC were analyzed and presented in Table 1.

Analytical results showed that electrical conductivity of the samples was generally low in all samples and ranged from 0.9 to $12.3 \mu \mathrm{S} \mathrm{cm}^{-1}$. pH of the samples ranged from 5.28 to 7.91. Samples varied in properties like SAR and RSC and it was about 0.06- 9.30 and less than 2.97 meq $\mathrm{I}^{-1}$ respectively. Carbonate content in water was less than 0.80 meq $^{-1}$ and bicarbonate content in the water ranged from $0.60-4.00$ meq $\mathrm{I}^{-1}$ respectively.Boron content recorded within permissible limits and it was ranged from 0.09 to $0.18 \mathrm{mg} \mathrm{l}^{-1}$. Chloride content ranged from $106.5-350 \mathrm{mg} \mathrm{l}^{-1}$. Observations showed that EC, SAR and boron were low, but RSC ranged from low to medium level. Presence of heavy metals such as lead, chromium and nickel was found to be negligible and/or within the permissible limits in kitchen waste water (Table 2). Biochemical oxygen demand of kitchen waste water is 32.10 $\mathrm{mg} \mathrm{l}^{-1}$ which is safe for irrigation purpose. Mineral elements viz. calcium, magnesium, sodium and potassium present in the kitchen waste water is higher than normal fresh water but it is within the permissible limit. It was found that all the parameters tested were within the safe limits and water is suitable or moderately suitable for irrigation.
Table 1: Quality parameters of Kitchen waste water in comparison with fresh water

\begin{tabular}{|c|c|c|c|}
\hline \multirow[t]{2}{*}{ Parameters } & \multicolumn{2}{|c|}{ Kitchen waste water } & \multirow{2}{*}{$\begin{array}{l}\text { Fresh } \\
\text { water }\end{array}$} \\
\hline & Ranges & Class & \\
\hline $\mathrm{pH}$ & 5.28 to 7.91 & & 6.01 \\
\hline $\mathrm{EC}\left(\mu \mathrm{S} \mathrm{cm} \mathrm{cm}^{-1}\right)$ & 0.90 to 9.70 & Low & 40 \\
\hline SAR & 0.06 to 9.30 & Low & 1.46 \\
\hline $\mathrm{RSC}($ meq l-1) & $<2.97$ & $\begin{array}{l}\text { Low to me- } \\
\text { dium }\end{array}$ & 1.67 \\
\hline Boron (mg l-1) & 0.09 to 0.18 & Low & 0.21 \\
\hline Chloride $\left(\mathrm{mg} \mathrm{l}^{-1}\right)$ & $\begin{array}{c}106.50 \text { to } \\
350.00\end{array}$ & $\begin{array}{l}\text { Safe to mod- } \\
\text { erately safe }\end{array}$ & $\mathrm{BDL}$ \\
\hline CO32- $\left(\mathrm{mg} \mathrm{l}^{-1}\right)$ & $<0.80$ & & Nil \\
\hline HCO3- $\left(\mathrm{mg} \mathrm{l}^{-1}\right)$ & 0.60 to 4.00 & & 0.50 \\
\hline Potassium (mg $\left.\right|^{-1}$ ) & 3.19 to 45.68 & & 4.88 \\
\hline Sodium $\left(\mathrm{mg} \mathrm{l}^{-1}\right)$ & 1.15 to 161.46 & & 12.17 \\
\hline Calcium (mg |-1) & 1.52 to 12.46 & & 4.92 \\
\hline $\begin{array}{l}\text { Magnesium (mg } \\
\left.\left.\right|^{-1}\right)\end{array}$ & 11.14 to 14.62 & & 1.02 \\
\hline
\end{tabular}

${ }^{*}$ BDL- Below detectable level

Table 2: Heavy metal content in kitchen waste water in comparison with fresh water

\begin{tabular}{lccc}
\hline Parameters & $\begin{array}{c}\text { Kitchen } \\
\text { waste water }\end{array}$ & $\begin{array}{c}\text { Fresh } \\
\text { water }\end{array}$ & $\begin{array}{c}\text { Permissible } \\
\text { limit }\end{array}$ \\
\hline Lead $\left(\mathrm{mg} \mathrm{l}^{-1}\right)$ & $<0.019$ & $\mathrm{BDL}$ & $5 \mathrm{mg} \mathrm{l}^{-1}$ \\
Nickel $\left(\mathrm{mg} \mathrm{l}^{-1}\right)$ & $<0.003$ & $\mathrm{BDL}$ & $0.2 \mathrm{mg} \mathrm{l}^{-1}$ \\
Chromium $\left(\mathrm{mg} \mathrm{l}^{-1}\right)$ & $\mathrm{BDL}$ & $\mathrm{BDL}$ & $0.01 \mathrm{mg} \mathrm{l}^{-1}$ \\
\hline
\end{tabular}

\subsection{Field tests in vegetable crops}

Field experiment in okra (var. Arka anamika) was conducted to compare the performance of crop irrigated by kitchen waste water and normal fresh water. Observations on growth of the crop showed that height and number of leaves in the two treatments were on par even though the growth of the crop irrigated with kitchen waste water was higher than well water (Table 3). Phenotypic observations showed no toxic symptoms on plants. Observation on yield characters such as fruit weight and number of fruits showed that yield of the crop irrigated using kitchen waste water was $6.20 \mathrm{~kg} \mathrm{plot}^{-1}$ while

\begin{tabular}{lccc}
\hline \multicolumn{4}{l}{ Table 3: Effect of irrigation water on growth of okra } \\
\hline Irrigation water & $\begin{array}{c}\text { Height of } \\
\text { plant }(\mathrm{cm})\end{array}$ & $\begin{array}{c}\text { No. } \\
\text { leaves }\end{array}$ & $\begin{array}{c}\text { No. of } \\
\text { fruits }\end{array}$ \\
\hline Kitchen waste water & 29.95 & 12.30 & 390 \\
Well water & 28.95 & 12.00 & 320 \\
$p<0.05$ & NS & NS & NS \\
\hline
\end{tabular}


it was only $4.10 \mathrm{~kg} \mathrm{plot}^{-1}$ with well water (Figure 1). Higher yield in kitchen waste water irrigated crops may be due to the presence of more mineral nutrients. Soil analysis also showed that nutrient content in the kitchen waste water treatment was higher than the normal fresh water applied plot (Table 4).

\subsection{Field tests in fish farming}

Fish farming using kitchen waste water showed that Tilapia variety grows well and gained to an average weight of $200 \mathrm{~g}$ in six months. Heavy metal content in the fish was only below the detectable level. Average biological oxygen demand of the water was $32.1 \mathrm{mg} \mathrm{l}^{-1}$ which is suited for aquatic life while the normal fresh water was only $2.5 \mathrm{mg} \mathrm{l}^{-1}$.

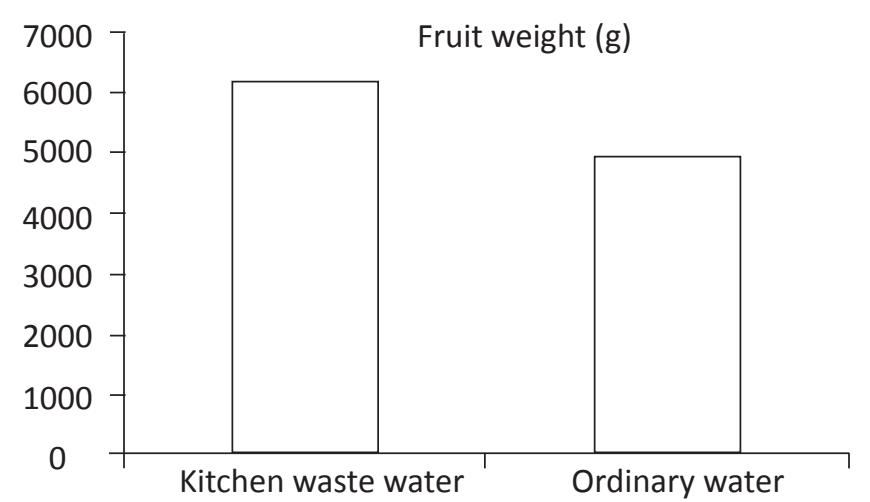

Figure 1: Fruit weight of Okra irrigated by different sources of water

Table 4: Comparison of soil nutrient content in kitchen waste water and fresh water applied plot

\begin{tabular}{|c|c|c|c|c|c|c|c|c|c|c|}
\hline & $\mathrm{pH}$ & $\begin{array}{c}E C \\
\left(\mathrm{ds} \mathrm{m}^{-1}\right)\end{array}$ & $\begin{array}{c}\text { Organic } \\
\text { carbon (\%) }\end{array}$ & $\begin{array}{c}\mathrm{P} \\
\left(\mathrm{kg} \mathrm{ha}^{-1}\right)\end{array}$ & $\begin{array}{c}\mathrm{K} \\
\left(\mathrm{kg} \mathrm{ha}^{-1}\right)\end{array}$ & $\begin{array}{c}\mathrm{Ca} \\
\left(\mathrm{mg} \mathrm{l}^{-1}\right)\end{array}$ & $\begin{array}{c}\mathrm{Mg} \\
\left(\mathrm{mg} \mathrm{l}^{-1}\right)\end{array}$ & $\begin{array}{c}\mathrm{Cu} \\
\left(\mathrm{mg} \mathrm{l}^{-1}\right)\end{array}$ & $\begin{array}{c}\mathrm{Zn} \\
\left(\mathrm{mg} \mathrm{l}^{-1}\right)\end{array}$ & $\begin{array}{c}\mathrm{B} \\
\left(\mathrm{mg} \mathrm{l}^{-1}\right)\end{array}$ \\
\hline $\begin{array}{l}\text { kitchen waste water } \\
\text { applied plot }\end{array}$ & 6.44 & 1.02 & 0.389 & 415.1 & 1915.2 & 114.5 & 22 & 1.94 & 0.443 & 0.808 \\
\hline $\begin{array}{l}\text { Fresh water applied } \\
\text { plot }\end{array}$ & 6.21 & 0.812 & 0.302 & 314.5 & 795.5 & 103 & 14.5 & 2.18 & 3.52 & 0.898 \\
\hline
\end{tabular}

\section{Conclusion}

Quality analysis of kitchen waste water for irrigation purpose showed that all chemical characteristics including heavy metal content were within the permissible limit and it is suitable or moderately suitable for irrigation. Field tests in vegetable crop, okra showed better performance of the crop compared to well water. Results of the study showed that kitchen waste water can be used for irrigation purpose in okra without undergoing any treatment.

\section{Acknowledgement}

Project funded by All India Co-ordinated Research Project on Irrigation Water Management is thankfully acknowledged.

\section{References}

Abdel-Halim, W., Weichgrebe, D., Rosenwinkel, K.H., Verink, J., 2008. Sustainable sewage treatment and re-use in Developing countries. Twelfth International Water Technology Conference, IWTC, Alexandria, Egypt.

Angelakis, A.N., Mays, L.W., Koutsoyiannis, D., Mamassis, N., 2012. Evolution of water supply through the Millennia. IWA Publishing.Com, 584.

Chaillou, K., Gerente, C., Andres, Y., Wolbert, D., 2011. Bathroom Greywater Characterization and Potential Treatments for Reuse of Water. Air and Soil Pollution 215, 31-42.

Karpiscak, M.M., Foster, K.E., Schmidt, N., 1990. Residential water conservation. Water Research 26: 939-948.

Lavik, G., Stuhrmann, T., Bruchert, V.V., 2009. Detoxification of sulphidic African shelf waters by blooming chemolithotrophs. Nature 457, 581-586.

Murali, G., Lakshmipriya, 2014. Residential greywater naturally by using canna plant at zero cost. Proceedings of the international conference on waste management for sustainable development organized by Department of civil engineering, NSS college of Engineering, Palakkad, Kerala from 21-23 March 2014, 137-141.

Nwakonobi., Ukamaka , T., Onwuegbucha., Nwadiuto , C., Enyi, O.S., 2015. A Filtration System for Treatment of Kitchen Waste Water for Re-Use. International Journal of Scientific and Engineering Research 6(10), 596-600.

Okun, D.A., 1997. Distributing reclaimed water through dual systems. American Water Works Association Journal 89, 153-160.

Singh, D., Chhonkar, P.K., Dwivedi, B.S., 2010. Manual on Soil, Plant and Water Analysis, Westville Publishing House, New Delhi, 93-111.

Swetha, R., Nandini, P., Preethi,R., Asmitha, V., 2013. Low energy intensive kitchen waste water treatment. International Journal of Applied Engineering Research 8(17), 2037-2042.

Tandon, H.L.S., 1993. Methods of analysis of soils, plants, waters, and fertilizers. Fertiliser Development and Consultation Organisation, New Delhi, 143. 